\title{
Inactivation of Alkaline Phosphatase and Shelf Life Extension of Milk Processed by Hurdle Technology
}

\author{
A. Shivani Indumathi*, G. Sujatha, D. Baskaran, B. Dhanalakshmi \\ and A. Serma Saravana Pandian
}

Food Technology, Tamil Nadu Veterinary and Animal Sciences University College of food and Dairy Technology, Koduveli, Chennai-600052, India

*Corresponding author

K e y w o r d s
Enzyme
inactivation, Hurdle
Technology, Pulsed
electric field, Shelf
life, Raw milk

A B S T R A C T

\section{Introduction}

Consumers demand for fresh, safe food with favorable sensory properties and nutritional properties with an adequate shelf life of the food products. In recent years there is a considerable interest in hurdle technology for the processing of foods and beverages. The hurdle Technology (HT) is the combination of two or more preservation techniques (Khan et al., 2017). The innovative technology of using a high voltage Pulsed electric field (PEF) for food preservation appears to be promising especially when combined with other preservation methods. The popularity of minimally processed foods has brought increased attention to preserve through the use of combined technique (Smith et al., 2008). 
Milk is a highly perishable food. The enzyme present in the milk plays a vital role in microbial growth. Milk contains high nutrient content and its rich composition serves ideal medium for the growth of micro organisms.

The proteins and lipids present in the milk are broken down by enzyme which leads to microbial growth. Thus the shelf life of milk is even limited at refrigerated conditions (Craven et al.2008). Proteases and lipase are the enzymes present in the milk that are produced by psychrotrophic bacteria. These enzymes hydrolyse milk proteins and leads to development of off flavours and rancidity (Zhang et al., 2015).

Alkaline phosphatase is an enzyme that is naturally present in milk. Alkaline phosphatase test is the index for proper pasteurization. Proper pasteurization confirms the destruction of enzyme.

Alkaline phosphatase enzyme is more heat resistant than most pathogenic bacteria (Fadiloglu et al., 2004).

Thermal treatments are used to inactivate the alkaline phosphatase. However, this method can affect the organoleptic and nutritional properties such as dissolved mineral, calcium, phosphorus and also damage the whey protein (Hadi et al., 2016). Hence this study is envisaged to investigate the activity of alkaline phosphatase and shelf life extension of milk by hurdle technology treatment by combining the effects of PEF and mild heat.

\section{Materials and Methods}

The raw milk was obtained from the nearby local farms around Alamathi - Koduveli village. Platform test such as clot on boiling and sensory analysis were done initially to check the quality of the milk.

\section{Hurdle processing of raw milk}

\section{Hurdle treatment}

Raw milk samples were heated to $40^{\circ} \mathrm{C}$ and $50^{\circ} \mathrm{C}$. The heated milk samples were filled in a lab model pulsed electric field (PEF) chamber comprising of the two stainless steel circular parallel plate electrodes. The lab model PEF system was used for processing the milk samples under hurdle technology. The PEF system produced square pulses of 2.5 $\mu \mathrm{s}$ pulse width with a maximum voltage gradient of $40 \mathrm{KV}$ with variable frequency. The milk was treated at different voltage levels $(10 \mathrm{KV} / \mathrm{cm}, 20 \mathrm{KV} / \mathrm{cm}$ and $30 \mathrm{KV} / \mathrm{cm})$ with different time periods ( 3 minutes and 6 minutes). The treated samples were collected using sterile glass bottles and compared with the pasteurized milk to study the presence or absence of alkaline phosphatase and shelf life of milk stored at refrigerated temperature.

\section{Alkaline phosphate test}

$1.5 \mathrm{~g}$ of sodium bicarbonate and $3.5 \mathrm{~g}$ of anhydrous sodium carbonate was dissolved in water and made up to one litre. $0.15 \mathrm{~g}$ of substrate (di sodium para nitrophenyl phosphate) was taken in $100 \mathrm{ml}$ measuring cylinder and made up to $100 \mathrm{ml}$ with buffer solution. $1 \mathrm{ml}$ of milk was taken in a sterile test tube and $5 \mathrm{ml}$ of para nitro phenyl phosphate buffer substrate was added to it and closed with a sterile rubber cork. The test tubes were kept in water bath at a temperature of $37^{\circ} \mathrm{C}$ for $2 \mathrm{hrs}$ and the change in color was noted.

\section{Results and Discussion}

Inactivation of Alkaline Phosphate in hurdle technology processed raw milk at different voltage gradients, time and temperature in the Table 1.The raw milk treated at $10 \mathrm{KV} / \mathrm{cm}$ at $40^{\circ} \mathrm{C}$ and $50^{\circ} \mathrm{C}$ for 6 minutes showed the 
absence of alkaline phosphatase enzyme. The raw milk treated at $20 \mathrm{KV} / \mathrm{cm}$ and $30 \mathrm{KV} / \mathrm{cm}$ at $40^{\circ} \mathrm{C}$ and $50^{\circ} \mathrm{C}$ for 3 and 6 minutes showed the absence of alkaline phosphatase.

Shelf life extension of hurdle technology processed raw milk at different voltage gradients, time and temperature in the Table 2.The mean values of $16.33 \pm 0.21,21.67 \pm$ $0.33,16.83 \pm 0.40,21.67 \pm 0.33,21.33 \pm 0.21$,
$21.83 \pm 0.40,21.33 \pm 0.49,26.33 \pm 0.21$, $27.00 \pm 0.26,31.50 \pm 0.22,26.50 \pm 0.22$, $30.83 \pm 0.17,10.50 \pm 4.10,4.00 \pm 0.63$ were obtained respectively for various treatments $\left(\mathrm{T}_{1}: \mathrm{T}_{12}\right)$, control and raw milk. It was observed that the shelf life of HT treated samples were highly significant $(\mathrm{p}<0.01)$ when compared to control samples. It was also observed that there was a significant difference $(p<0.01)$ between treatments.

Table.1

\begin{tabular}{|c|c|c|c|c|}
\hline \multirow{2}{*}{$\begin{array}{c}\text { Treatment } \\
\text { temperature }\end{array}$} & \multicolumn{2}{|c|}{$40^{\circ} \mathrm{C}$} & \multicolumn{2}{c|}{$50^{\circ} \mathrm{C}$} \\
\cline { 2 - 5 } & Treatment time & \multicolumn{2}{|c|}{ Treatment time } \\
gradient $(\mathrm{KV} / \mathrm{cm})$ & $\mathbf{3 m i n}$ & $\mathbf{6 m i n}$ & $\mathbf{3 m i n}$ & $\mathbf{6 m i n}$ \\
\hline 10 & & - & - & - \\
\hline 20 & - & - & - & - \\
\hline 30 & - & - & - & - \\
\hline Control milk & - & - & \\
\hline
\end{tabular}

Table.2

\begin{tabular}{|c|c|c|}
\hline HT treatment parameters & Treatment & $\begin{array}{c}\text { Mean values } \\
\text { (shelf life in days) }\end{array}$ \\
\hline $10 \mathrm{KV} 40^{\circ} \mathrm{C} 3 \mathrm{mins}$ & $\mathrm{T}_{1}$ & $16.33 \pm 0.21^{\mathrm{c}}$ \\
\hline $10 \mathrm{KV} 40^{\circ} \mathrm{C} 6 \mathrm{mins}$ & $\mathrm{T}_{2}$ & $21.67 \pm 0.33^{c}$ \\
\hline $10 \mathrm{KV} 50^{\circ} \mathrm{C} 3 \mathrm{mins}$ & $\mathrm{T}_{3}$ & $16.83 \pm 0.40^{\mathrm{d}}$ \\
\hline $10 \mathrm{KV} 50^{\circ} \mathrm{C} 6 \mathrm{mins}$ & $\mathrm{T}_{4}$ & $21.67 \pm 0.33^{\mathrm{e}}$ \\
\hline $20 \mathrm{KV} 40^{\circ} \mathrm{C} 3 \mathrm{mins}$ & $\mathrm{T}_{5}$ & $21.33 \pm 0.21^{\mathrm{d}}$ \\
\hline $20 \mathrm{KV} 40^{\circ} \mathrm{C} 6 \mathrm{mins}$ & $\mathrm{T}_{6}$ & $21.83 \pm 0.40^{\mathrm{d}}$ \\
\hline $20 \mathrm{KV} 50^{\circ} \mathrm{C} 3 \mathrm{mins}$ & $\mathrm{T}_{7}$ & $21.33 \pm 0.49^{\mathrm{e}}$ \\
\hline $20 \mathrm{KV} \mathrm{50} 0^{\circ} \mathrm{C} 6 \mathrm{mins}$ & $\mathrm{T}_{8}$ & $26.33 \pm 0.21^{\mathrm{e}}$ \\
\hline $30 \mathrm{KV} 40^{\circ} \mathrm{C} 3 \mathrm{mins}$ & $\mathrm{T}_{9}$ & $27.00 \pm 0.26^{\mathrm{d}}$ \\
\hline $30 \mathrm{KV} 40^{\circ} \mathrm{C} 6 \mathrm{mins}$ & $\mathrm{T}_{10}$ & $31.50 \pm 0.22^{d}$ \\
\hline $30 \mathrm{KV} 50^{\circ} \mathrm{C} 3 \mathrm{mins}$ & $\mathrm{T}_{11}$ & $26.50 \pm 0.22^{f}$ \\
\hline $30 \mathrm{KV} \mathrm{50}{ }^{\circ} \mathrm{C} 6 \mathrm{mins}$ & $\mathrm{T}_{12}$ & $31.83 \pm 0.17^{\mathrm{f}}$ \\
\hline Control & & $10.50 \pm 4.10^{b}$ \\
\hline Raw milk & & $4.00 \pm 0.63^{\mathrm{a}}$ \\
\hline $\mathbf{F}$ & & $43.441 * *$ \\
\hline
\end{tabular}


The inactivation of alkaline phosphatase is observed in all the HT treated samples. This is due to the hurdles (PEF and mild heat) applied to the milk samples. The electric field strength, pulse duration of PEF treatment, mild heat influenced the inactivation of alkaline phosphatase and resulted in shelf life extension (Barsotti and Cheftel, 1999). The Duncan's analysis was carried out to find homogeneous subsets. The values revealed that the shelf life was highly significant $(p<0.01)$ between the treatments. The mean values showed that the shelf life of raw milk subjected to treatment $\mathrm{T}_{12}$ (30 KV $50^{\circ} \mathrm{C} 6 \mathrm{mins}$ ) had greater shelf life compared to the other treatments. As the electric field intensity, PEF treatment time and temperature was greater than the other treatments, the HT treated samples $\left(\mathrm{T}_{12}\right)$ had a greater shelf life (Heinz et al., 2003).

In conclusion, hurdle Technology treatment (PEF and mild heat) inactivated alkaline phosphatase and reduced the microbial load which increased the shelf life of the treated milk with acceptable sensory attributes. It was inferred that the effectiveness of the inactivation level was increased by increasing the treatment time and voltage gradient.

\section{Acknowledgement}

The authors acknowledge the help provided by the Department of Dairy Science, Madras Veterinary College and Department of Food Process Engineering, College of Food and Dairy Technology, TANUVAS for utilizing the lab facilities for PEF processing and quality control analysis.

\section{References}

1. Barsotti, L., and Cheftel, J. C. 1999. Food processing by pulsed electric fields. II. Biological aspects. Food Reviews International, 15(2): 181-213.

2. Craven, H. M., P. Swiergon, S. Ng, J. Midgely, C. Versteeg, M. J. Coventry and Wan J. 2008. Evaluation of pulsed electric field and minimal heat treatments for inactivation of pseudomonads and enhancement of milk shelf-life. Innovative food science \& emerging technologies, 9(2): 211-216.

3. Fadiloglu, S., O. Erkmen and Sekerogwlu, G. 2004. Thermal and carbon dioxide inactivation of alkaline phosphatase in buffer and milk. Food Technol. Biotechnol. 42 (1): 27-32.

4. Hadi, A., S. B. Widjanarko and Kusnadi, J. 2016. Testing of Commercial Milk Production Technology Using A Combination of High Temperature Short Time And Pulsed Electric Field. Int J Dairy Process Res, 3(1), 29-34.

5. Heinz, V., S. Toepfl and Knorr, D. 2003. Impact of temperature on lethality and energy efficiency of apple juice pasteurization by pulsed electric fields treatment. Innovative Food Science \& Emerging Technologies, 4(2): 167-175.

6. Khan, I., C. N. Tango, S. Miskeen, B. H. Lee and Oh, D. H. 2017. Hurdle technology: A novel approach for enhanced food quality and safety-A review. Food Control, 73: 1426-1444.

7. Smith, K., G. S. Mittal and Griffiths, M. W. 2008. Pasteurization of Milk Using Pulsed Electrical Field and Antimicrobials. Journal of Food Science, 67:2304 2308.

8. Zhang, S., H. Li, H. Uluko, L. Liu, X. Pang and Lv, J.2015. Investigation of Protease Production by Pseudomonas fluorescens BJ-10 and Degradation on Milk Proteins. Journal of food processing and preservation, 39(6): 2466-2472.

\section{How to cite this article:}

Shivani Indumathi, A., G. Sujatha, D. Baskaran, B. Dhanalakshmi and Serma Saravana Pandian, A. 2018. Inactivation of Alkaline Phosphatase and Shelf Life Extension of Milk Processed by Hurdle Technology. Int.J.Curr.Microbiol.App.Sci. 7(07): 3278-3281.

doi: https://doi.org/10.20546/ijcmas.2018.707.381 